\title{
Unusual becoming Usual: recent persistent-rainstorm events and their implications for debris flow risk management in the northern Apennines of Italy
}

\author{
Alessandro Corsini ${ }^{(1)}$, Giuseppe Ciccarese ${ }^{(1)}$, Giovanni Truffelli (2) \\ 1) University of Modena and Reggio Emilia - Department of Chemical and Geological Sciences, via Giuseppe Campi 103, \\ 41125 Modena, Italy \\ 2) Emilia-Romagna Region - Regional Agency for Civil Protection and Territorial Security, Strada Giuseppe Garibaldi 75, 43121 \\ Parma, Italy
}

\begin{abstract}
The alluvial events of Parma (13 October 2014) and Piacenza (13-14 September 2015) in the northern Apennines of Italy have had significant effects in terms of flooding and morphological changes along the main and secondary rivers of the affected areas. The paper presents a summary of the characteristics of the rainstorm events, as well as of the triggered debris flows and their consequences on infrastructures. In the perspective of an extremization of rainfall regimes as a consequence of ongoing climate changes, these phenomena might become quite usual in the future and should be further studied in order to define regional-specific triggering thresholds, analyse precursors from weather radar datasets and assess susceptibility on a regional scale basis.
\end{abstract}

Keywords Debris Flows, rainstorms, northern Apennines.

\section{Introduction}

The alluvial events of Parma (13 October 2014) and Piacenza (13-14 September 2015) have had significant effects in terms of flooding and morphological changes along the main and secondary rivers in upper Val Parma, Val Baganza Val d'Aveto, Val Nure, Val Trebbia (AIPO, 2014; ARPAE-SGSS, 2016). These events have been caused by severe rainstorms characterized by hourly rainfall peaks higher than $80 \mathrm{~mm}$ and rainfall duration between 6 hours (Piacenza) and 9 hours (Parma). Along the slopes and the streams, these rainstorm events have triggered several debris flows, causing damages to hydraulic works and road infrastructure networks.

Debris flows are quite common in the Alps (Arattano \& Moia, 1998; Berti et al., 1999; Cavalli \& Grisotto, 2005; Marchi \& D'Agostino, 2004; Pavlova et. al., 2014) but are considered unusual in the Emilia-Romagna Apennines. However, debris flows have occurred in Emilia Romagna Region also in the past, for instance during the alluvial events of Piacenza (Val Trebbia) in September 1953 and Modena, Reggio Emilia e Parma provinces in September 1972 and September 1973 (Moratti \& Pellegrini, 1977; Papani \& Sgavetti, 1977; Rossetti \& Tagliavini, 1977).

This short note, which derives from the summary of the works of Corsini et al. (2015) e Ciccarese et al. (2016), presents the rainfall data recorded during the alluvial events of 2014 and 2015, the distribution and characteristics of debris flows triggered during the events and the damages caused to the infrastructure.

\section{Rainstorm events}

\section{Parma province event of 13 October 2014}

During the alluvial event of 13 October 2014, debris flows have occurred in Val Parma and Val Baganza, along the slopes of Monte Cervellino-Monte Vitello (municipalities of Corniglio, Berceto and Calestano) (Fig.la).

The rain-gauge of Marra, part of ARPAE (Regional Agency for Prevention, Environment and Energy) monitoring network located in the area affected by debris flows, has recorded, between $12^{\text {th }}$ and $13^{\text {th }}$ October 2014, a rainfall of $308.6 \mathrm{~mm}$ in 24 hours (Fig.1b). The hourly rainfall data show higher rainfall intensity values between 7.00 and 15.00 of $13^{\text {th }}$ October 2014. The maximum hourly rainfall peak recorded has been of $81.8 \mathrm{~mm} / \mathrm{h}$. These rainfall intensity values are associated to return period exceeding 100 years and are above almost any of debris flow triggering rainfall thresholds presented in scientific literature (Caine, 1980; Ceriani et al., 1992; Cannon \& Gartner, 2005; Crosta \& Frattini, 2001; Innes, 1983; Marchi et al., 2002; Paronuzzi et al., 1998; Wieczorek, 1987) (Fig.1c).

\section{Piacenza province event of 12-13 September 2015}

During the alluvial event of $13^{\text {th }}$ and $14^{\text {th }}$ September 2015 several debris flows have occurred in Val d'Aveto, Val Nure and Val Trebbia (particularly affected were the municipalities of Ferriere, Cerignale and Ottone) (Fig.2a).

The rainstorm event has occurred between 22.00 of $13^{\text {th }}$ and 03.00 of $14^{\text {th }}$ September and the rainfall data have been recorded by ARPAE rain-gauges in the mountain basins of Trebbia and Nure rivers.

All stations have recorded rainfall values higher than $200 \mathrm{~mm}$ in 24 hours. The Salsominore rain-gauge, located in the area mostly affected by debris flow, has recorded rainfall values of $329 \mathrm{~mm}$ in 24 hours (maximum value recorded in the area) and hourly rainfall intensity peak (at 
01.30 o'clock) of $107.6 \mathrm{~mm}$ (Fig.2b). The highest hourly precipitation peaks have been recorded by rain-gauges located at higher altitudes: the rain-gauge of Cabanne has recorded a hourly rainfall peak of $123.6 \mathrm{~mm}$.

The rainfall values recorded by all rain-gauges are above the thresholds presented in scientific literature (Caine, 1980; Ceriani et al., 1992; Cannon \& Gartner, 2005; Crosta \& Frattini, 2001; Innes, 1983; Marchi et al., 2002; Paronuzzi et al.,1998; Wieczorek, 1987) (Fig.2c).

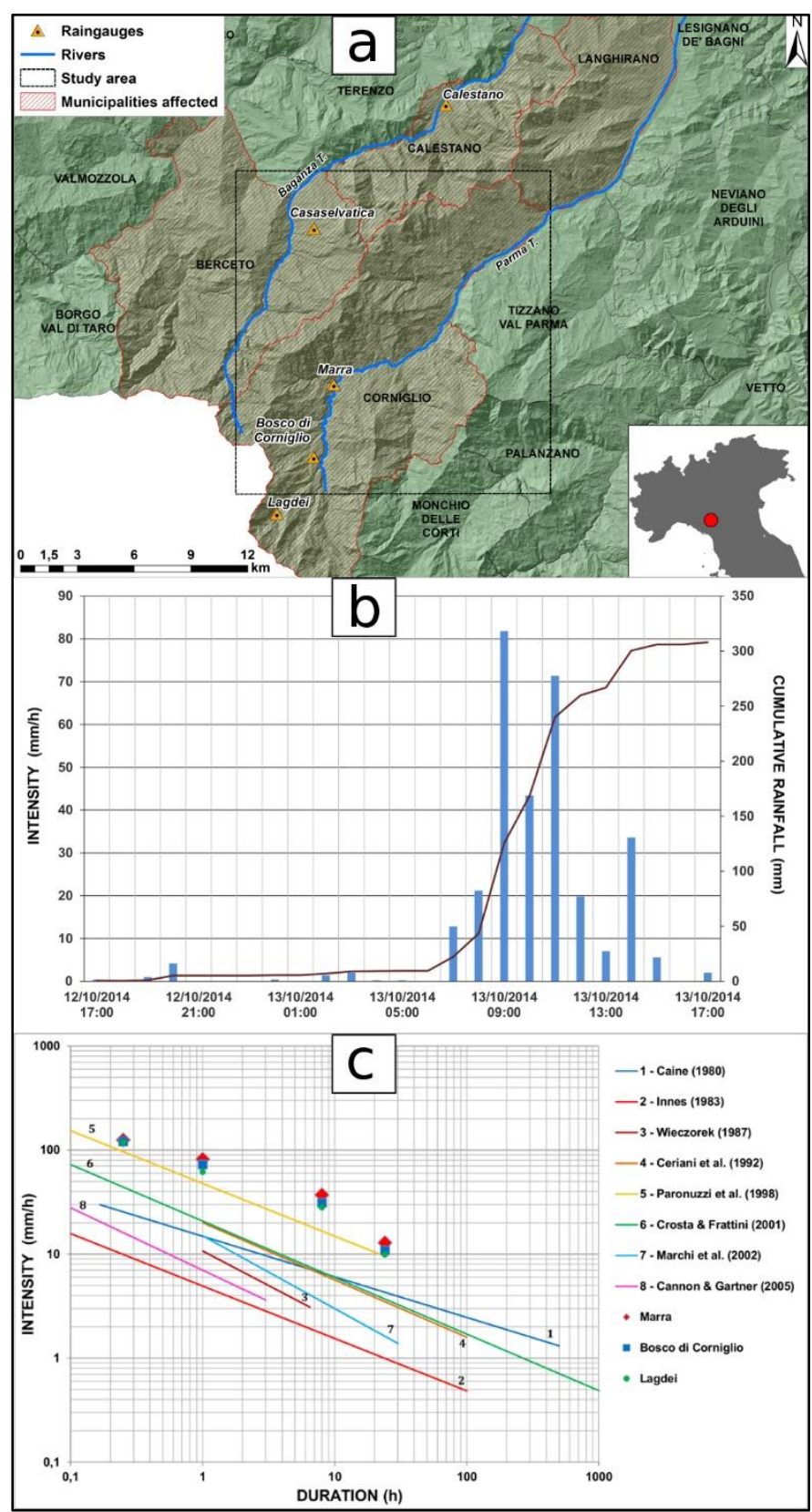

Fig. 1 - a) Area affected by debris flows during the Parma province alluvial event of 2014; b) rainfall data recorded by ARPAE raingauge of Marra during the alluvial event; c) comparison between rainfall data recorded by 3 raingauges and some rainfall thresholds triggering debris-flow proposed in scientific literature.

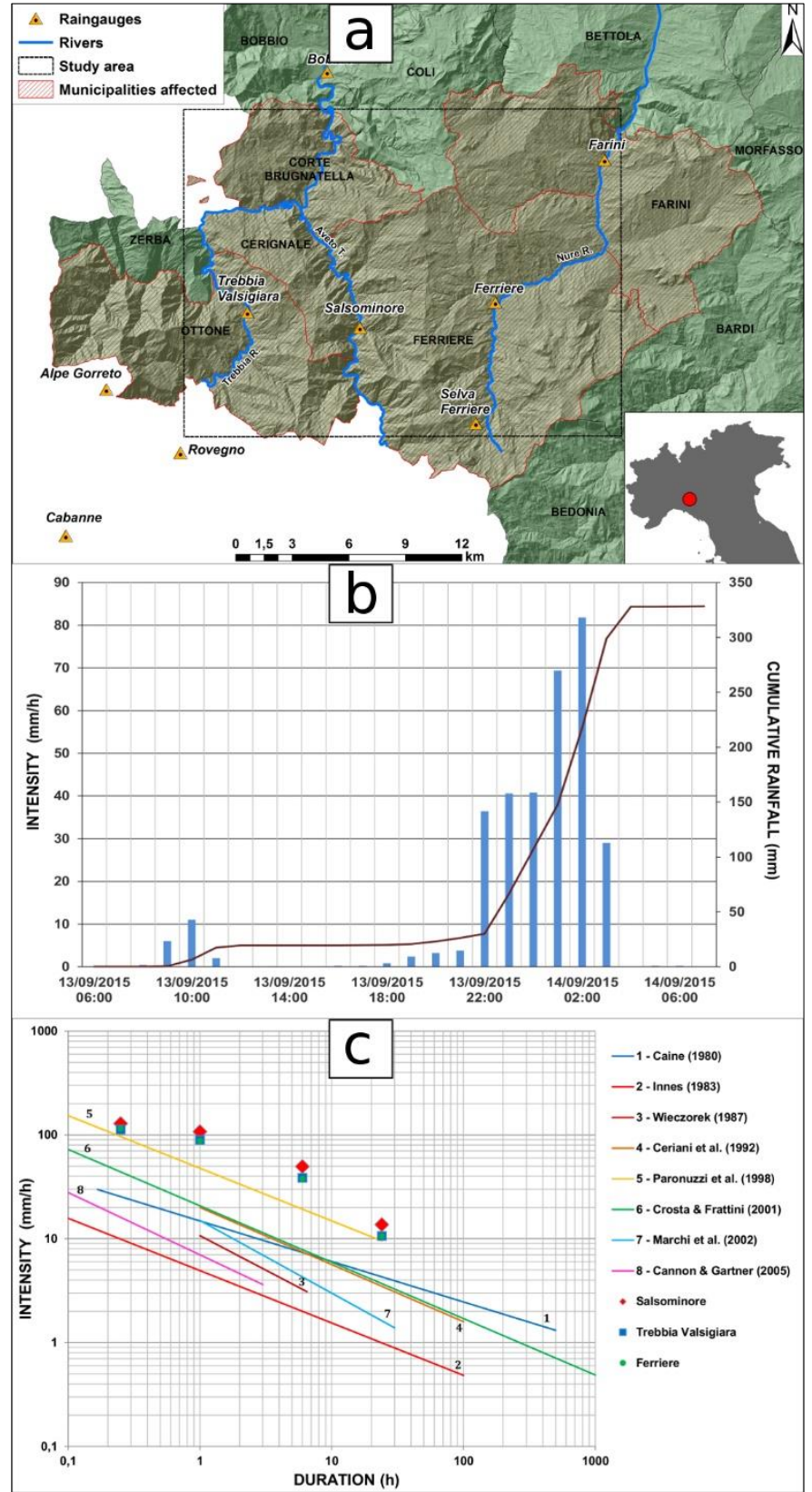

Fig. 2 - a) Area affected by debris flows during the Piacenza province alluvial event of 2015; b) rainfall data recorded by ARPAE raingauge of Salsominore during the alluvial event; c) comparison between rainfall data recorded by 3 raingauges and some rainfall thresholds triggering debris-flow proposed in scientific literature.

\section{Debris flows occurrence}

\section{Parma province event of 13 October 2014}

During the field surveys performed a few days after the event in Val Parma and Val Baganza, 26 debris flows have been identified along the torrents (Fig.3a). The length of the torrent tracks affected by debris flows ranges from $1000 \mathrm{~m}$ to $3000 \mathrm{~m}$. The altitude difference between the triggering zone and the final accumulation ranges from $600 \mathrm{~m}$ to $150 \mathrm{~m}$.

Bedrock lithology is flysch with sandstone or limestone components prevailing on pelitic component and mono-polygenic breccia. The triggering zones 
correspond, in many cases, to areas of marked changes in slope gradient where coarse debris deposits has affected by rotational- translational slides. In the case of Rio Vestana more than $10.000 \mathrm{~m}^{3}$ of coarse debris have been mobilized (Fig.3b).

Along the channels, streambed scouring and debris deposits have been documented. Furthermore, the debris levees shows the typical inverse gradation of debris flow deposits (Fig.3C).

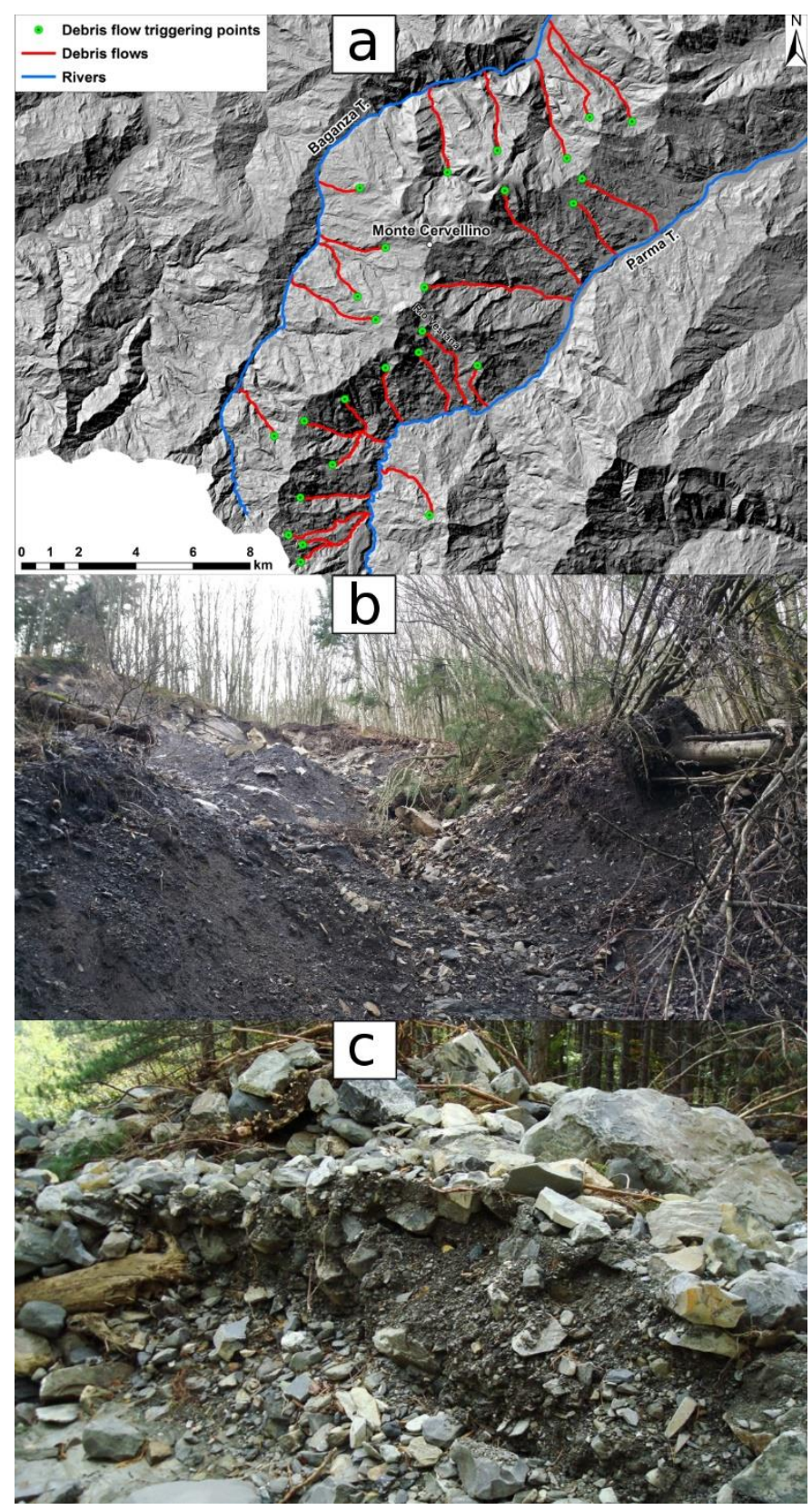

Fig. 3 - a) Map of debris flows distribution during the event of September 2014 in Parma province: torrents affected and triggering points; b) example of debris flow triggering zone documented in Parma province; c) debris flow deposit documented along Rio Vestana: levees with inverse gradation of debris flow deposits in Rio Vestana.

\section{Piacenza province event of 12-13 September 2015}

The field surveys and the analysis of post-event satellite and aerial images have concerned an area of around $350 \mathrm{~km}^{2}$ comprising various sub-basins of Trebbia River, Nure Torrent and Aveto Torrent. Slope instability phenomena have been surveyed and mapped, including 113 debris flows (Fig.4a), 89 debris slides, 4 mud flows and 29 erosion on the banks. Furthermore, 110 debris flows triggering zones have been identified and mapped in form point: $57 \%$ of the phenomena surveyed has affected the sub-basins of the Aveto Torrent, $24 \%$ the sub-basins of the Nure Torrent and 19\% those of the Trebbia River.

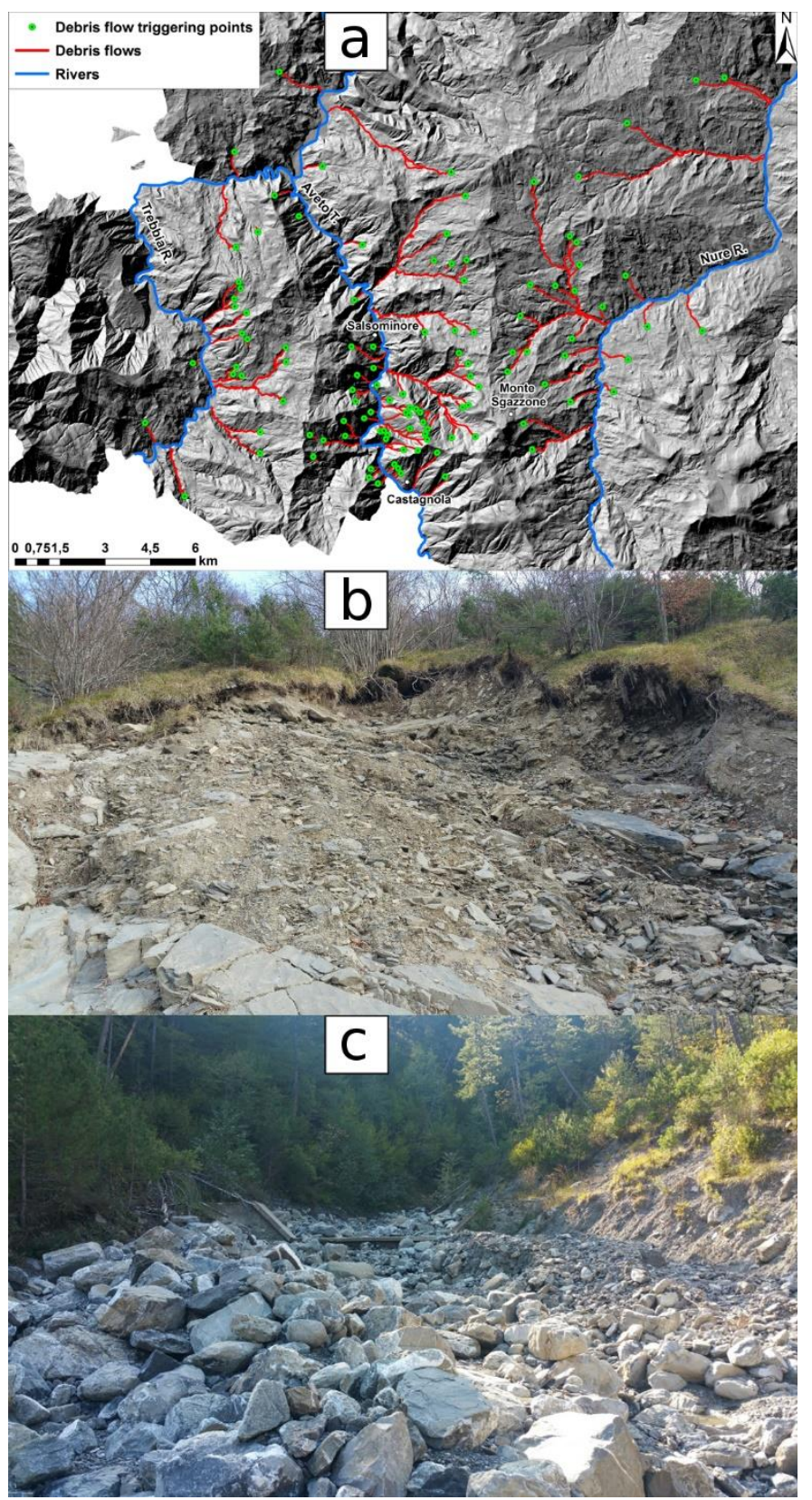

Fig. 4 - a) Map of debris flows distribution during the event of October 2015: torrents affected and triggering points; b) example of debris flow triggering zone documented in Piacenza province; c) debris flow deposit zone documented in Piacenza province along a torrent affected by debris flow: channel overrun by debris. 
The sites of Salsominore and Castagnola, in Ferriere municipality (Val d'Aveto), along the slopes of Monte Sgazzone, are the areas mostly affected by debris flows during the rainstorm event.

The triggering zones correspond to areas in the upper part of the sub-basins where slope debris has been remobilized by rotational and translational slides and subsequently transported along the track channel (Fig.4b).

In $71 \%$ of the triggering zones identified, bedrock lithology is Flysch with an arenite or sandstone component prevailing over the pelite component and in in $29 \%$ is chaotic melangés with a dominant pelite component.

In most cases, the thickness of debris remobilized from the triggering zones is 5-7 $\mathrm{m}$. The thickness reached by debris flows in the track channel is higher than 4-5 $\mathrm{m}$ (Fig.4c). Furthermore, in many torrents, the erosive action of debris flows has caused failures along the sides of the channel.

\section{Effects on infrastructures}

During the Parma province alluvial event, several check dams along the torrents affected by debris flows were destroyed or buried by debris (Fig. 5a). Consequently, large amounts of debris previously trapped upstream of the check-dams, have been mobilized along the channel. Severe damages have affected many local roads crossing the debris flow tracks (Fig.5b), mostly where the torrents have been previously channeled into $1 \mathrm{~m}$ diameter pipes under the roads. In these cases, the flow-pipes have been rapidly obstructed by the debris flows, causing the overflow of debris and the erosion and cut-through of the road track (Fig. 5c).

Similarly, during the Piacenza province alluvial event, the most relevant damages have suffered by the roads in the points of intersection with the channels affected by debris flows. In some cases, the same road has been crossed by debris flows in several sections (Fig.6a).The accumulations of debris reached thicknesses up to $2 \mathrm{~m}$ (Fig.6b).

In the fan-shaped accumulation zones at the confluence of the torrents into the main rivers large amounts of debris have overflowed the roads and, in the case of Rio Ruffinati, a hydropower plant (Fig.6c).

\section{Conclusions}

As demonstrated by the events of Parma 2014 and Piacenza 2015, as well as by the "historical" events ì Reggio Emilia-Modena in 1972 or Piacenza 1953, the occurrence of debris flows in Emilia Romagna Apennines is not to be considered so unusual as previously thought. Moreover, in the perspective of an extremization of rainfall regimes as a consequence of ongoing climate changes, these phenomena might become quite usual in the future.

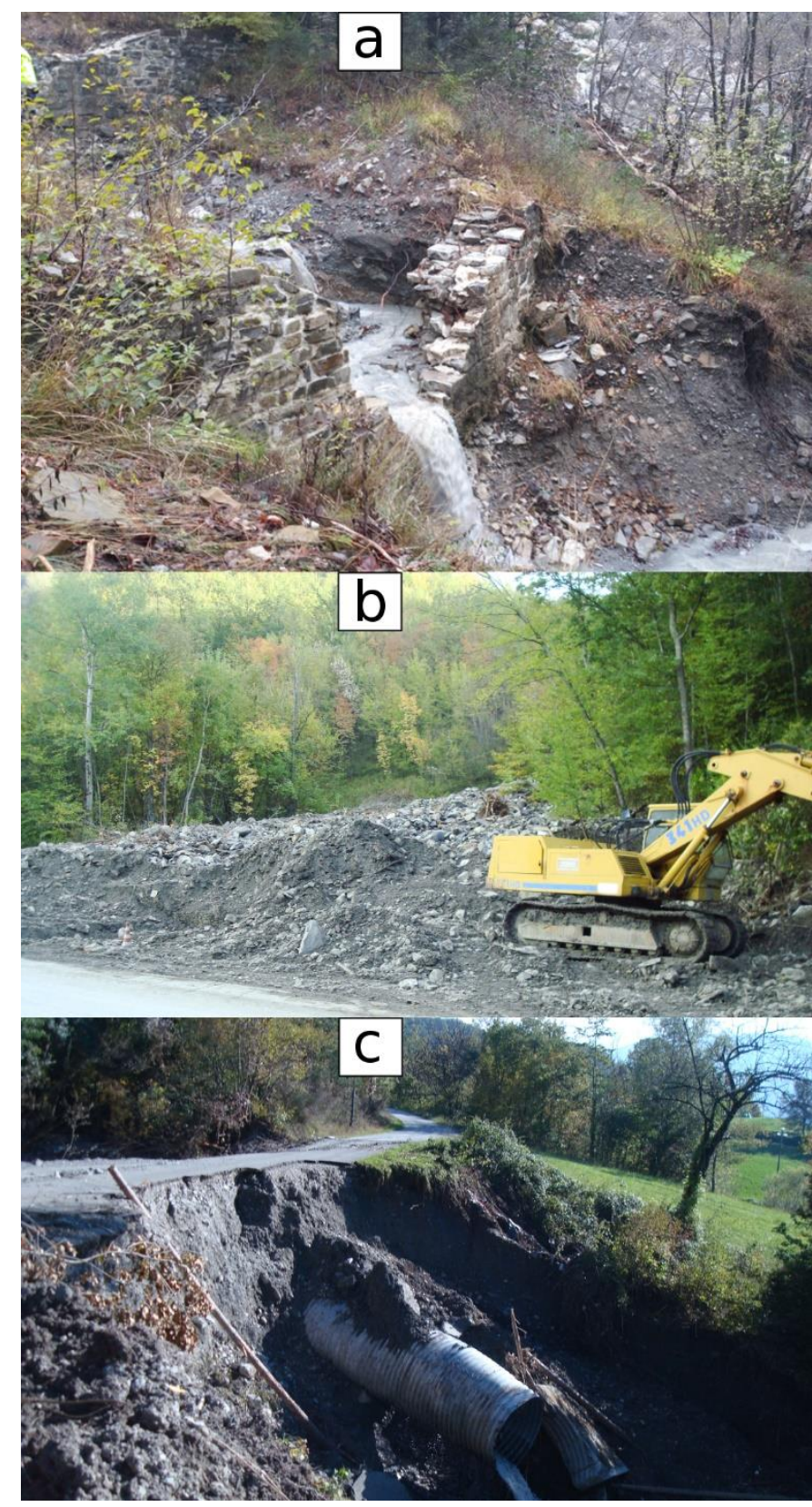

Fig. 5 - Example of effects on infrastructures in Parma province: a) check-dams cut-through by debris flows; b) road overrun by debris; c) erosion and cut-through of the road track.

Their implications for debris flow risk management in the northern Apennines of Italy attain to the following problems: (i) definition of alert thresholds, which take into account the rainfall regimes of the different portions of the territory, to overcome the limits consequent to the use of a single threshold value (as indicated in DGR n ${ }^{\circ} 962 / 2018$ ); (ii) analysis of the correlation between radar weather data, lightning and debris flows occurrence (Ciccarese et al., 2017 e Corsini et al., 2017); (iii) susceptibility and hazard mapping in order to take into account the predisposing hydro-morphometric and geological characteristics and the probability of exceeding the triggering rainfall threshold values. Research on these topics has been started and, while ongoing, has already provided some 
significant results that allow raising the level of attention on this type of phenomena.

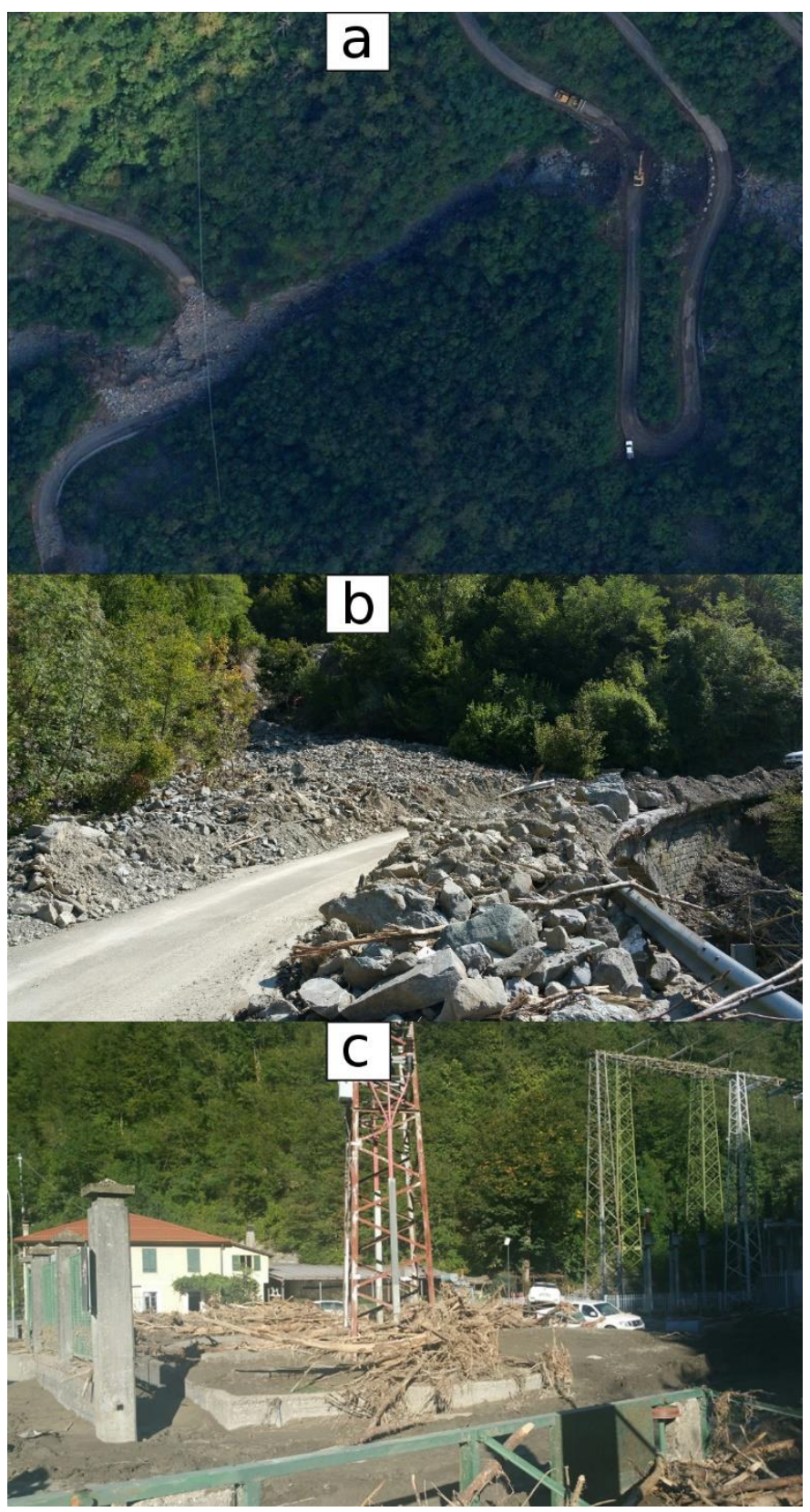

Fig. 6 - Example of effects on infrastructures in Piacenza province: a) aerial photo of a local road that crosses the debris flow in many sections; b) debris flow deposit along the local road; c) hydropower plant of Ruffinati overrun by debris.

\section{Acknowledgments}

This work was supported by the Emilia-Romagna Region Agency for Civil Protection and Territorial Security, under the framework of the partnership agreement for "Research, technical, scientific and informative activities on support to the forecast, prevention and management of hydrogeological risk - 2016-2021" (responsible A. Corsini).

\section{References}

AIPO (Agenzia Interregionale per il Fiume Po) (2014). Relazione preliminare sugli eventi di Parma e Baganza del 13-14 ottobre 2014. www.agenziapo.it/file/1361/download?token=CPOw CZgp

Arattano M. \& Moia F. (1998). Monitoring the propagation of a debris flow along a torrent Hydrological Sciences Journal, 44 (5), pp. 811-823.

ARPAE-SGSS (ARPAE Servizio Idro Meteo Clima, Servizio Geologico Sismico e dei Suoli) (2016). Rapporto sull'evento alluvionale del 14 settembre 2015. http://ambiente.regione.emiliaromagna.it/geologia/notizie/notizie-2016/rapportosullevento-alluvionale-del-14-settembre-2015

Berti M., Genevois R., Simoni A., Tecca P.R. (1999). Field observations of a debris flow event in the Dolomites. Geomorphology 29, 265-274.

Caine N. (1980) - The rainfall intensity duration control of shallow landslides and debris flow. Geografiska Annaler, 62 (1-2), 659-675.

Cannon S.H. \& Gartner, J.E. (2005). Wildfire-related debris flow from a hazards perspective. In Debrisflow hazards and related phenomena (pp. 363-385). Springer Berlin Heidelberg.

Cavalli M. \& Grisotto S. (2005). GIS-based identification of debris flow dominated channels: application to the upper Avisio Basin (Trento). Servizio Sistemazione Montana della Provincia Autonoma di Trento, Interreg III Project Alpine Space, Work Package 7, Innovative Tools for Information Collection.

Ceriani M., Lauzi, S., Padovan N. (1992). Rainfalls and landslides in the alpine area of Lombardia region, central Alps, Italy. In Proc. Int. Symp. Interpraevent (pp. 9-20).

Ciccarese G., Corsini A., Pizziolo M., Truffelli G. (2016). Debris Flows in Val Nure and Val Trebbia (northern Apennines) during the September 2015 alluvial event In Piacenza Province (Italy). Rendiconti Online della Società Geologica Italiana, 41, 127-130

Ciccarese G., Corsini A., Alberoni P.P., Celano M., Fornasiero A. (2017). Using Weather Radar Data (Rainfall and Lightning Flashes) for the analysis of Debris Flows occurrence in Emilia-Romagna Apennines (Italy). Advancing Culture of Living with Landslides. Springer International Publishing, 4, 437 $-448$.

Corsini A., Ciccarese G., Diena M., Truffelli G., Alberoni, P.P., Amorati R. (2017). Debris flows in Val Parma and Val Baganza (northern Apennines) during the 12-13th October 2014 alluvial event in Parma province (Italy) - Italian Journal of Engineering Geology and Environment, Special Issue 2017, 29-38. 
Corsini A., Ciccarese G., Berti M., Diena M., Truffelli G. (2015). Debris flows in Val Parma and Val Baganza (northern Apennines) during the October 2014 alluvial event in Parma Province (Italy) - Rendiconti Online della Società Geologica Italiana, 35, 85-88.

Crosta G. \& Frattini P. (2001). Rainfall thresholds for the triggering of soil slips and debris flows. In Mediterranean Storms 2000 (pp. 463-488).

Genevois R., Tecca P.R., Berti M., Simoni A. (200o) Debris flow in the Dolomites: experimental data from a monitoring system - G. Wieczorek, N. Naeser (Eds.), Proceedings, Second International Conference on Debris-flow Hazard Mitigation: Mechanics, Prediction, and Assessment, A.A. Balkema, Rotterdam, pp. 283-291.

Innes J.L. (1983). Debris flows. Progress in physical geography, 7(4), 469-501.

Marchi L., Arattano M., Deganutti A.M. (2002). Ten years of debris-flow monitoring in the Moscardo Torrent (Italian Alps). Geomorphology, 46(1), 1-17.

Marchi L. \& D'Agostino V. (2004). Estimation of the debris-flow magnitude in the Eastern Italian Alps Earth Surface Processes and Landforms, 29, pp. 207220.

Moratti L. \& Pellegrini M. (1977). Alluvioni e dissesti verificatisi nel settembre 1972 e 1973 nei bacini dei fiumi Secchia e Panaro (Province di Modena e Reggio Emilia). Bollettino della Associazione Mineraria Subalpina, Anno XIV, n.2, pp. 323-374.

Papani G. \& Sgavetti M. (1977) - Aspetti geomorfologici del bacino del T. Ghiara (Salsomaggiore Terme, PR) susseguenti all'evento del 18-09-1973. Bollettino dell'Associazione Mineraria Subalpina, 14, n. 3-4, 610628.

Paronuzzi P., Coccolo A., Garlatti G. (1998). Eventi meteorici critici e debris flows nei bacini montani del Friuli. L'Acqua, Sezione I/Memorie, 6, 39-50.

Pavlova I., Jomelli V., Brunstein D., Grancher D., Martin E., Déqué M. (2014) - Debris flow activity related to recent climate conditions in the French Alps: A regional investigation. Geomorphology. 219, 248-259.

Rossetti G. \& Tagliavini S. (1977) - L'alluvione ed i dissesti provocati nel bacino del Torrente Enza dagli eventi meteorologici del settembre 1972 (Province di Parma e Reggio Emilia). Bollettino dell'Associazione Mineraria Subalpina, 14, n. 3-4, 561-603.

Wieczorek G.F. (1987). Effect of rainfall intensity and duration on debris flows in central Santa Cruz Mountains, California. Reviews in Engineering Geology, 7, 93-104. 